\title{
Palaeoecological analysis of Sentolo Formation based on foraminifera fossil assemblage from stratigraphic cross-sectional measurements in Pengasih, Kulon Progo, Yogyakarta
}

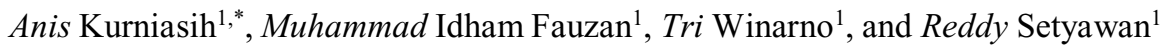 \\ ${ }^{1}$ Departement of Geological Engineering Universitas Diponegoro, Semarang, Indonesia
}

\begin{abstract}
Sentolo formation that is included in the Kulon Progo stratigraphic series has a wide distribution. Although there have been a number of studies on it, more detailed research is needed, as there are still many unexplored outcrop locations. Moreover, there are still a lot of questions about the stratigraphic relationship between Sentolo Formation and Oligocene-Miocene volcanic series of Kulon Progo. Based on this background, this study is focused on the existence of foraminifera fossil in Sentolo Formation as an indicator of palaeoecological conditions at the time Sentolo Formation was deposited. This research is very important to get a detail understanding about the indicators that are influential at the time of deposition process of Sentolo Formation in research area. Based on palaeoecological analysis, the palaeoecology at the time Sentolo Formation deposited was normal marine continental slope waters. Meanwhile, the community structure of foraminifera indicates a stable water conditions in a marine environment that was not disrupted by volcanism, so it becomes a good factor for the growth of foraminifera. Whereas the presence of volcaniclastic material mixed with carbonate which is occurred in the lower part of Sentolo Formation were interpreted as reworked of older volcanic rock.
\end{abstract}

\section{Research Background}

Foraminifera is a single-celled organism that inhabits marine waters. Although it is a microorganism, the dead foraminifera can be preserved in sediments and rocks for hundreds or even millions of years. In geology, foraminifera fossils are widely used to interpret the relative age and depositional environments of rocks. Foraminifera occur since the Paleozoic Period until recently and has undergone evolution so that many types of foraminifera became the index of certain geological age. The foraminifera fossil in rocks 
can also be used as an indicator of ecological conditions when the fossil-containing rocks are formed in an environment or referred as paleoecology.

The Sentolo formation that is included in the Kulon Progo stratigraphic series is fairly wide spread. Researchers such as [1-3] have studied stratigraphic aspects of the Sentolo Formation. Although there have been number of studies on the Sentolo Formation, more detailed research is needed, as there are still many unexplored outcrop locations. The study can be focused on the existence of foraminifera fossil in Sentolo Formation rocks as a guideline of paleoecological conditions at the time the Sentolo Formation was deposited. This research is very important to identify the condition of aquatic ecology at the time of foraminifera lived and the relation between volcanism process that happened in Oligocene Miocene with deposition of Sentolo Formation in research area.

The ecological condition of aquatic environment measured directly to water samples, which include carbonate, salinity, and temperature. However, this measurement method is not possible in the paleo-aquatic environment, because the existing waters must have undergone a change of condition. Therefore, paleoecological analysis is applicable to sediments or rocks deposited in an environment and one of its methods is by analyzing the abundance of foraminifera fossil contained in the rocks or sediments.

\section{Methods}

1. Foraminifera analysis

The planktonic foraminifera classification is based on [4] and for benthic foraminifera based on $[5,6]$. Once the foraminifera are identified, the presentation of each taxon in every sample is displayed in foraminifera distribution chart.

2. Planktonic and benthic foraminifera ratio $\mathrm{P} / \mathrm{B}$ Ratio)

The ratio of individual presence of planktonic and benthic foraminifera is used as an indicator of the water depth.

3. Community structure

The community structure of foraminifera is expressed in diversity index, similarity, and dominance index. Diversity is the number of species or taxon contained within a community. It is difficult to determine diversity. Therefore, the method of calculating diversity in this study is conducted using the Shannon - Wiener index [7] or H, with the following criteria:

$$
\begin{aligned}
& \mathrm{H}<1=\text { low diversity } \\
& 1<\mathrm{H}<3=\text { medium diversity } \\
& \mathrm{H}>3=\text { high diversity }
\end{aligned}
$$

The uniformity index is the pattern of distribution of each taxon whether it is evenly or not. If the uniformity index is relatively high, the existence of each type of foraminifera in a waters is in a uniform condition. The uniformity index is expressed in Evennes Index (e), with the criterion of e $<0.3$ showing the uniformity is low; e $=0.3$ 0.6 is moderate; and e $>0.6$ is high [7].

The dominance index is used to obtain information about the domination of a taxon in a particular community. It is ranges from zero to one. If the value is close to 1 then the foraminifera community is dominated by a particular species and if it is close to 0 then no dominant species [7].

4. MRT triangular diagram

Triangular diagrams are based on the three sub-ordo of foraminifera abundance, which are distinguished by their test compositions; agglutinated, porcelain, and hyaline. The triangular diagram may be an indicator of carbonate content, dissolved oxygen, and salinity. 


\section{Research Location}

The research location covers the area of Pengasih, Kulon Progo Regency. Overall, there are seven detailed stratigraphic measurement locations scattered in the southwest and northeast part of the study area.

\section{Results and Discussion}

\subsection{Lithostratigraphy and Biostratigraphy of Sentolo Formation}

In general, the stratigraphic cross-sectional measurement is more focused on the Sentolo Formation, especially at the lowest part where there is direct contact with the older formation of the Old Andesite Formation (OAF) and the middle part of the formation. Stratigraphic measurements were carried out at 7 locations spread in two areas, in the southwest and north-east. There are 5 sections in the southwest; i.e. Serang1, Serang2, Serang3, Clereng, and Sidomulyo. While in the northeast there are 2 sections, Kiskendo and Bubrah, both sections have contact with OAF.

Overall, the lithostratigraphic character of Sentolo Formation in research area from the bottom most layer is as follows:

1. The lower part of Sentolo Formation

The lower part of Sentolo Formation can be observed in the Kiskendo and Bubrah sections. Based on its megascopic appearance, the lower stratigraphy of the Sentolo Formation in the study area is composed of sandstones, as well as calcarenite and calcilutite unconformly laid above volcanic breccia of OAF member.

From the petrographic observation of calcarenite sample JGK1, taken from Kiskendo section, microscopically is composed by abundant skeletal grain comprising planktonic foraminifera. In addition, there is also non-skeletal grain of feldspar, which is estimated to be the result of volcanic rock reworking deposited along with foraminifera.

2. The middle part of Sentolo Formation

A different character of Sentolo Formations sedimentary rock layers found on Serang 1, Serang 2, Serang 3, Clereng, and Sidomulyo section. Based on the strike and dip of the rock layers, these sections are younger than Bubrah and Kiskendo sections. In general, the rock layers in the sections are composed of calcarenite and calcilutite, which are intercalated and contain ichnofossils. The microscopic characteristic seen in SS-1 rock samples from Serang1 section are the abundance of the foraminifera microfossil contents. The mineral feldspar as non-skeletal grain as found in the sample on the older track is not present in this rock sample.

Biostratigraphic analysis conducted in this study included determination of the relative age of rocks using [8] foraminifera biozonation. The determination of the planktonic microfossil relative age of each rock samples can be observed in Table 1.

\subsection{Paleoecological Analysis Based on Foraminifera Fossil Assemblage}

\subsubsection{Paleobathymetry}

Paleobatimetric analysis was performed using planktonic and benthic foraminifera ratio (P/B Ratio), which then classified using [9] classification to obtain the bathymetry 
accordingly. The marine environment determination was conducted based on [10]. The paleobathymetry analysis of each samples can be seen in Table 2 .

Table 1. Relative age determination based on planktonic foraminifera analysis.

\begin{tabular}{|c|c|l|l|}
\hline Section & Sample & \multicolumn{1}{|c|}{ Relative age } & \multicolumn{1}{|c|}{ Index fossil } \\
\hline Kiskendo & JGK 1 & Early-Middle Miocene (N7-N8) & Globigerinoides diminitus \\
\hline \multirow{2}{*}{ Bubrah } & KB 1 & Early-Middle Miocene (N7-N8) & Globigerinoides diminitus \\
\cline { 2 - 4 } & KB 2 & Early-Middle Miocene (N7-N8) & Globigerinoides diminitus \\
\cline { 2 - 4 } & KB 3 & Early-Middle Miocene (N7-N8) & Globigerinoides diminitus \\
\hline \multirow{2}{*}{ Serang1 } & SS 1 & Middle Miocene (N12) & Globorotalia fohsi \\
\hline \multirow{2}{*}{ Serang2 } & SS 2.1 & Middle - Late Miocene (N7-N18) & $(-)$ \\
\cline { 2 - 4 } & SS 2.2 & Middle Miocene - Pliocene (N13-N19) & $(-)$ \\
\hline Serang3 & SS 3 & Middle - Late Miocene (N13-N18) & $(-)$ \\
\hline Sidomulyo & TS 1 & Middle Miocene (N12) & Globorotalia fohsi \\
\hline Clereng & JJC 1 & Middle - Late Miocene (N13-N15) & $(-)$ \\
\hline & JJC 2 & Middle - Late Miocene (N9-N17) & $(-)$ \\
\hline
\end{tabular}

Table 2. Paleobathymetry analysis using P/B Ratio.

\begin{tabular}{|c|c|c|c|c|c|}
\hline Section & Sample & $\begin{array}{c}\text { Plankton } \\
\text { percentage (\%) }\end{array}$ & $\begin{array}{c}\text { Water depth (m) } \\
\text { according to [9] }\end{array}$ & $\begin{array}{c}\text { Bathymetry } \\
\text { according to } \\
{[\mathbf{1 0 ]} .}\end{array}$ \\
\hline Kiskendo & JGK 1 & 63,63 & $680-825 \mathrm{~m}$ & & Upper Slope \\
\hline \multirow{2}{*}{ Bubrah } & KB 1 & 55,50 & $550-700 \mathrm{~m}$ & & Upper Slope \\
\hline & KB 2 & 74,00 & $700-1100 \mathrm{~m}$ & & Upper Slope \\
\hline & KB 3 & 75,12 & $700-1100 \mathrm{~m}$ & & Upper Slope \\
\hline Serang 1 & SS 1 & 73,56 & $680-825 \mathrm{~m}$ & & Upper Slope \\
\hline Serang 2 & SS 2.1 & 78,20 & $700-1100 \mathrm{~m}$ & & Upper Slope \\
\hline & SS 2.2 & 67,87 & $680-825 \mathrm{~m}$ & & Upper Slope \\
\hline Serang 3 & SS 3 & 66,14 & $680-825 \mathrm{~m}$ & & Upper Slope \\
\hline Sidomulyo & TS 1 & 63,04 & $680-825 \mathrm{~m}$ & & Outer Shelf \\
\hline Clereng & JJC 1 & 30,18 & $100-600 \mathrm{~m}$ & & Upper Slope \\
\hline & JJC 2 & 60,39 & $680-825 \mathrm{~m}$ & & Upper Slope \\
\hline
\end{tabular}

\subsubsection{Community structure of foraminifera}

The distribution of benthic foraminifera fossil population on 11 samples of rock representing all stratigraphy cross-sectional of Sentolo Formation in research are calculated using PAST program as seen in Table 3 to obtain its community structure.

Based on the calculation of benthic foraminifera fossil community mentioned above, it is known that the number of taxa that is determined in all samples ranges from 4 to 14 taxa. The population of foraminifera individuals is very abundant so as to describe stable water conditions that enable the foraminifera community to live properly.

In addition, the results of the calculation of the dominance index on all samples close to zero, indicating that there were no taxon dominates among other taxa. The diversity 
index value of all samples entirely falls within the range of 1 to 3 , which means a moderate degree of foraminifera diversity. The last parameter is the index of similarity or evenness that varies in all samples. Almost on all samples, the evenness is moderate to high. While the evenness which less than 0.3 indicates the low uniformity, as in sample JJC1. Samples with high evenness are generally samples with small individuals, though none of the taxon dominates. From these analyses, it can be conclude that the condition of waters at the time of foraminifera benthic lived was stable.

Table 3. The result of community structure analysis of benthic foraminifera using PAST software.

\begin{tabular}{|l|l|l|l|l|l|l|l|l|l|l|l|}
\hline & SS3 & SS2.1 & SS2.2 & SS1 & KB1 & KB2 & KB3 & JGK1 & JJC1 & JJC2 & TS1 \\
\hline Taxa & 11 & 4 & 7 & 10 & 10 & 10 & 8 & 9 & 14 & 7 & 4 \\
\hline Individuals & 108 & 46 & 80 & 55 & 85 & 65 & 54 & 68 & 229 & 101 & 85 \\
\hline Dominance (D) & 0.20 & 0.30 & 0.19 & 0.19 & 0.17 & 0.23 & 0.17 & 0.17 & 0.43 & 0.31 & 0.38 \\
\hline Shannon (H) & 1.90 & 1.28 & 1.76 & 1.89 & 1.98 & 1.79 & 1.85 & 1.89 & 1.37 & 1.42 & 1.15 \\
\hline Evenness(e) & 0.61 & 0.90 & 0.83 & 0.66 & 0.72 & 0.60 & 0.80 & 0.74 & 0.28 & 0.59 & 0.79 \\
\hline
\end{tabular}

To strengthen the results of community structural analysis, benthic foraminifera fossils found in each sample were grouped according to their test wall composition and analyzed using triangular MRT diagrams according to [11]. In the Fig. 1 it is seen that the classification of the waters condition where foraminifera lived or when the deposition of Sentolo Formation was normal marine continental slope waters.

Based on the results of the analyses can be interpreted that the condition of the waters at the time of fossil foraminifera lived is in stable and optimum conditions. If it is associated with volcanic activity during the Oligocene - Miocene in the research area, then it is likely that at the time of the foraminifera lived the activity of volcanism has stopped.

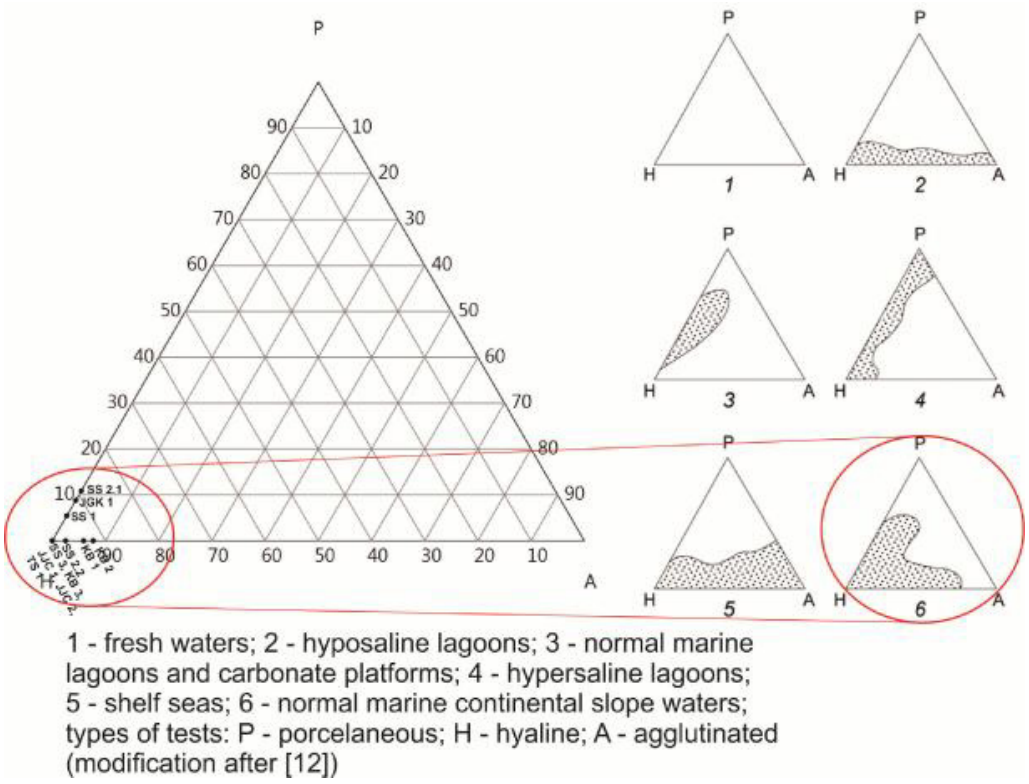

Fig. 1. Triangular diagram plotting of benthic foraminiferal assemblage 


\section{Conclusion}

Based on paleobathymetry and paleoecology of all samples, it can be concluded that Sentolo Formation was deposited at normal marine continental slope waters. Meanwhile, the community structure of foraminifera analysis indicates a stable water conditions with optimum level of carbonate content, oxygen supply, salinity, and temperature. According to the analysis, the palaeoecological condition at the time Sentolo Formation was deposited in the research area was a marine environment that was not disrupted by volcanic activity, so it becomes a good factor for the growth of foraminifera. Whereas the presence of volcaniclastic material mixed with carbonate which is occured in the lower part of Sentolo Formation (KB1, SS2.1 and SS2.2), were interpreted as reworking processes of older volcanic rocks.

The authors thank to Ilham Hani Pratama, Hanif Indra Wicaksana, Bagus Rachmad, Dewi Mindasari, Yan Bachtiar, Siti Rofikoh, and Kuncahyo Tantri as field and discussion partners. The thanks also go to parties who have been willing to provide corrections, criticisms, suggestions and input, so that the research and writing of this paper can be resolved.

\section{References}

1. R. W. Van Bemmelen, The Geology of Indonesia, Volume IA, General Geology of Indonesia and Adjencent Archipelago, $2^{\text {nd }}$ Edition (Government Printing Office, The Hague, 1949)

2. D. Kadar, Neogene Planktonic Foraminiferal Biostratigraphy of the South Central Java Area Indonesia (Geological Research and Development Centre Directorate General of Geology and Mineral Resources Ministry of Mines and Energy, Bandung, 1986)

3. W. Rahardjo, Sukandarrumidi, H. M. G. Rosidi, Peta Geologi Lembar Yogyakarta, Jawa skala 1:100.000 (Directorate General of Geology and Mineral Resources Ministry of Mines and Energy, Bandung, 1977)

4. J.A. Postuma, Manual of Planktonic Foraminifera (Elsevier Publishing Company, Amsterdam, 1971)

5. E. Boltovskoy, Mar. Geol., 26(1):139-175 (1978)

6. A.R. Loeblich, and H. Tappan, Foraminiferal Genera and Their Classification (Springer, New York, 1988)

7. E.P. Odum, Fundamentals of ecology Third Edition, (W.B. Saunders Company, Philadelphia, 1971)

8. W. H. Blow, Proc. of International Conference on Planktonic Microfossils 1, 199-422 (1969)

9. T. F. Grimsdale and F. P. C. M. Van Morkhoven, Proc. $4^{\text {th }}$. World Petroleum Congress 473-491 (1955)

10. H. L. Tipsword, F. M. Setzer, F. L. Smith Jr., G. C. Assoc. Geol. Soc. Transaction, 16, 119 - 130 (1966)

11. J.W. Murray, Ecology and paleoecology of benthic foraminifera (Longman Harlow, Essex, 1991)

12. B. Valchev, 50 years University of Mining and Geology "St. Ivan Rilski Annual, 189 194 (2003) 